\title{
Cutaneous Squamous Cell Carcinoma of the Head and Neck cN2a TNM Finding v8
}

National Cancer Institute

\section{Source}

National Cancer Institute. Cutaneous Squamous Cell Carcinoma of the Head and Neck cN2a TNM Finding v8. NCI Thesaurus. Code C133217.

Cutaneous squamous cell carcinoma of the head and neck with metastasis in a single ipsilateral lymph node larger than $3 \mathrm{~cm}$ but not larger than $6 \mathrm{~cm}$ in greatest dimension and ENE(-). (from AJCC 8th Ed.) 